\title{
Distribution of Indoor Air Pollutants in Downtown Rio de Janeiro, Brazil
}

\author{
Celeste Y. S. Siqueira, ${ }^{*, a}$ Adriana Gioda, ${ }^{b}$ Fabiana P. Carneiro, ${ }^{a}$ \\ Maria da Conceição K. V. Ramos ${ }^{a}$ and Francisco R. Aquino Neto ${ }^{a}$
}

${ }^{a}$ Laboratório de Apoio ao Desenvolvimento Tecnológico, Instituto de Química, Universidade Federal do Rio de Janeiro, Av. Athos da Silveira Ramos No. 149, Ilha do Fundão, Cidade Universitária, 21941-909 Rio de Janeiro-RJ, Brazil

${ }^{b}$ Departamento de Química, Pontifícia Universidade Católica do Rio de Janeiro, Rua Marquês de São Vicente No. 225, Gávea, CP 38097, 22453-900 Rio de Janeiro-RJ, Brazil

\begin{abstract}
A qualidade do ar de interiores (IAQ) tem sido um assunto de preocupação no Brasil. No entanto, poucos estudos têm sido realizados em todo o país. Este trabalho apresenta uma pesquisa sobre IAQ conduzida em diferentes tipos de ambientes fechados na cidade do Rio de Janeiro. Amostras de ar foram analisadas para determinar compostos orgânicos voláteis individuais e totais (TVOCs), aldeídos, matéria particulada total (TPM) e fungos. Dentre os parâmetros estudados, as

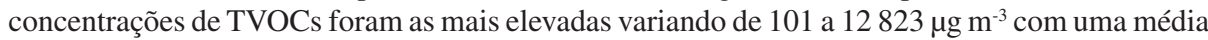
de $1594 \mu \mathrm{g} \mathrm{m}^{-3}$, ultrapassando o limite sugerido pela ANVISA ${ }^{7}\left(500 \mu \mathrm{g} \mathrm{m}^{-3}\right)$. A razão interna/externa para a maioria dos parâmetros foi maior que a unidade, indicando fontes internas de poluição. Por outro lado, baixos níveis de propágulos fúngicos (esporos) foram detectados (14-314 ufc m³),

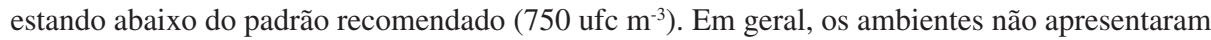
boa qualidade do ar para seus ocupantes devido principalmente aos poluentes químicos.
\end{abstract}

Indoor air quality (IAQ) has been a matter of public concern in Brazil. However, few studies have been performed in the whole country. This work presents an IAQ survey conducted in different kinds of indoor environments in Rio de Janeiro City. Air samples were analyzed to determine individual and total volatile organic compounds (TVOCs), aldehydes, total particulate matter (TPM) and fungi. TVOC concentrations ranged from 101 to $12823 \mu \mathrm{g} \mathrm{m}^{-3}$ with an average of $1594 \mu \mathrm{g} \mathrm{m}{ }^{-3}$, exceeding the suggested limit from $\operatorname{ANVISA}^{7}\left(500 \mu \mathrm{g} \mathrm{m}^{-3}\right)$. Indoor/outdoor ratios for most of the parameters were higher than unit, indicating indoor sources of pollution. On the other hand, low levels of airborne fungi were detected (14-314 $\mathrm{cfu}^{-3}$ ) being below than the ANVISA standard ${ }^{7}\left(750 \mathrm{cfu} \mathrm{m}^{-3}\right)$. Overall, the environments did not present good air quality for the occupants due to chemical pollutants.

Keywords: indoor air quality, volatile organic compounds, office, microbiological analyses, carbonyl compounds

\section{Introduction}

Air pollution is a major environmental health problem affecting developed and under developing countries around the world. Increasing amounts of potentially harmful gases and particles are being emitted into the atmosphere on a global scale, resulting in harm to human health and to the environment. Regarding indoor air, it plays an important role in the healthiness as people spend $88 \%$ of their day inside buildings, $7 \%$ in a vehicle, but only $5 \%$ of their

*e-mail: celesteyara@iq.ufrj.br time outdoors. Indoor exposures produce more harmful health effects than outdoor. The evidence is that indoor concentrations of many pollutants are often higher than those typically encountered outside. ${ }^{1}$

Indoor air quality studies are rare in Brazil. The first study registered was developed in 1990, when carbonyl levels of three indoor sites in Salvador City (Bahia State) were reported. ${ }^{2}$ That study focused on the relationship between ambient levels of acetaldehyde and the use of ethanol as an automobile fuel..$^{2}$ In that preliminary study, indoor/outdoor $(\mathrm{I} / \mathrm{O})$ ratios indicated the existence of significant indoor pollutants, including aldehydes 
emitted from works of art (that employed wood, glues, varnishes and lacquers) and infiltrated from the exterior as a result of alcohol-fueled vehicle emissions.

Following that research, the Southeastern Brazil Indoor

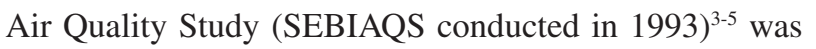
performed to obtain information on a wide range of airborne chemical species in indoor atmospheres, in a region also influenced by emissions from alcohol-fueled vehicles. This study contributed to the assessment of population exposure to a variety of gaseous and particulate pollutants present in the indoor environment. Measurements were made in a variety of non-industrial indoor environments to investigate aerosol and gas-phase pollutants in São Paulo and Rio de Janeiro Cities. ${ }^{3-5}$

Over the past two decades, Brazil has experienced an increase in the construction of sealed buildings due to various factors, e.g. architectural design trends, ambient conditioning and noise reduction. This tendency is increasing the problems of indoor air quality, when the air-conditioning systems are not adequately maintained. A recent population census also showed an intense urbanization in Brazil, with $84 \%$ of the population living in cities. Brazil has one of the world's megalopolis, São Paulo $\left(11 \times 10^{6}\right.$ inhabitants $)$ and a large city, Rio de Janeiro $\left(6 \times 10^{6}\right.$ inhabitants $)$. To preserve the health of occupants of these buildings, the Brazilian Government published guidelines for indoor air quality. ${ }^{6,7}$ Both guidelines suggested limits of indoor pollutants, established cleaning methods for heating, ventilation and air-conditioning (HVAC) systems, indicated emission sources of pollutants, aiming to prevent health risks to the occupants. However, many pollutants still need more information to define limits. Therefore, many more studies are necessary. In the last decade, some researchers have been studying indoor air quality in Brazil, with the objective of improving the quality of people's lives and of determining what kinds of pollutants are commonly present. Studies evaluating air quality in offices, ${ }^{8-10}$ dwellings ${ }^{11}$ and printing facility ${ }^{12}$ were performed in our laboratory. Most of these studies were developed in indoor environments where the occupants complained about health problems. The main physical and chemical parameters were investigated and mitigation programs were suggested. The results of these studies indicated that indoor air is more polluted than outdoor and this should be taken into consideration. In some of the studied locations, remediation was carried out to the indoor environments and the air quality was considerably improved. ${ }^{12}$

Important sources of chemical indoor pollutants include outdoor air, human body and human activities, emissions from building materials, furnishings and appliances and the use of consumer products. ${ }^{13,14}$ Microbial contamination is mostly related to the presence of humidity. The heating, ventilating and air-conditioning system can also act as pollutant sources, especially when not properly maintained. For example, the improper care of filters can lead to the re-emission of particulate contaminants. ${ }^{15}$

Considerable concern has been voiced over possible ill health effects from exposures to pollutants in indoor air, especially from volatile organic compounds (VOCs). VOCs are widespread indoor pollutants due to their popular use in several ways. Thus, they play an important role in indoor atmospheric chemistry. Some of these VOCs are considered potential risk factors for causing cancer in humans. A new definition of organic compounds in indoor air (OCIA) was proposed to roughly distinguish between four types of OCIAs according to their expected health effect, including odor annoyance. ${ }^{16}$

The aim of this research was to evaluate indoor air quality in environments where occupants presented some symptoms of health problems. The indoor environments were offices, a bank vault and carpentry situated in downtown Rio de Janeiro. The evaluated parameters were temperature, relative humidity, volatile organic compounds, aldehydes, total particulate matter and airborne fungi. Some of these environments were reevaluated after a mitigation program. This research could also become a reference scenario to evaluate VOC impact on health since the lower amounts in typical indoor environments hide the evaluation of cause-effect relationships.

\section{Experimental}

\section{Sampling sites}

Office building (ALC)

A cross-sectional study was carried out involving 151 full-time office workers of a sealed 17 storey office building. Samplings were carried out in a reformed office located on the $12^{\text {th }}$ floor of the building. The building was built in the decade of 1970, totally sealed, with HVAC systems. Sampling locations were selected after evaluation of the human activities and the air-conditioning systems. Three sampling points were chosen in the office: ALC_01, ALC_02 and ALC_03. The building is located in downtown Rio de Janeiro near a street with heavy traffic. The office was renewed a year before. It had artificial illumination during daytime and fully carpeted. Smoking is prohibited. The room was equipped with some computers, 5 laser printers, 3 photocopy machines and typical office tables and chairs.

\section{Office building (TRF)}

The evaluated 25 storey building has three floors used for garage space. Each inspected floor had a machine for a 
central air-conditioning system. Four floors were selected with one or two office rooms. The floors were: $10^{\text {th }}$ (1001 and $1003), 14^{\text {th }}(1401$ and 1403$), 15^{\text {th }}(1503)$ and $21^{\text {st }}(2101$ and 2103). The environments were quite similar: rooms with on average 5 occupants, some of them were smoking, floor covered by carpet, granite and plywood, shelves made of wood and plywood, some wooden chairs and tables, some computers, plants and photocopy machines.

The carpentry workshop, located in annex $2 \mathrm{~B}, 3^{\text {rd }}$ floor of the same building, was also evaluated. The room was approximately $120 \mathrm{~m}^{2}$, with 6 non-smoking occupants, granite floor, some wooden shelves, chairs and tables, computers, plants and photocopy machines. In this environment, two sampling points were chosen: M1 (workshop) and M2 (office). The carpentry is supplied by a central air-conditioning system. The building is located in the downtown area in a street with very heavy traffic.

\section{Office building (PET)}

The building has four sectors with approximately 390 occupants and $560 \mathrm{~m}^{2}$ per sector. These sectors are basically composed by office rooms. Ten sampling points, which are distributed in these sectors, were chosen to collect air samples (Table 1). The environments are similar and have tables, chair, computers, shelves and print/fax machines, i.e., common material to offices. Two sampling campaigns were carried out in this environment, one before a reform and the other one 3 months later after reforming. All rooms are supplied by central air-conditioning system. The building is located in the downtown area in a street with very heavy traffic.

\section{Bank vault of a commercial bank}

This is a single storey building, near a heavy traffic street. In this construction, three rooms were selected after evaluation of the human activities and the air-conditioning system: office room (SL), vault (CF), count room point 1 (CG1) and count room point 2 (CG2). The rooms are supplied by central air-conditioning system.

\section{Outdoor}

The metropolitan area of Rio de Janeiro is one of the twenty biggest urban agglomerations in the world (with 11 million inhabitants) and the first, among the Brazilian cities, in respect to the population density, with $1700 \mathrm{hab} \mathrm{km}^{-2}{ }^{17}$ Among the metropolitan regions in Brazil, Rio de Janeiro has the highest degree of urbanization (96.8\%) and responds for $80 \%$ of the internal income of the Rio de Janeiro State and $13 \%$ of the country. ${ }^{17}$ Rio de Janeiro is surrounded by mountains, coves and beaches, being located in the north of the Tropic of Capricorn along the Brazilian Atlantic Coast.
The terrain is characterized by steep hills and mountains which are offshoots of the mountain range Serra do Mar. These hills are granite based and lead inland to form the Brazilian Highlands. The center of the city (Central Zone) was built on a hill. As the city grew, this hill was later leveled and used as infill for expansion. The hills around Rio de Janeiro severely limited where and how much expansion could take place. ${ }^{17}$ Therefore, other areas were occupied such as the Southern Zone and Northern Zone. The Southern Zone is limited by hills and ocean. Northern Zone is much flatter and most of the development is concentrated along the western side of the Guanabara Bay. The Central Zone is characterized by big buildings and commercial activities. The South is basically designated to tourism and the North is characterized by industry. Rio de Janeiro City is situated at latitude $22^{\circ} 54^{\prime} \mathrm{S}$ and longitude $43^{\circ} 10^{\prime} \mathrm{W}$ and experiences a climate with high temperatures (20-40 $\left.{ }^{\circ} \mathrm{C}\right)$, high humidity $(70-80 \%)$ and abundant rainfall averaging $2381 \mathrm{~mm} \mathrm{y}^{-1}$.

\section{Sampling strategy and analytical measurements}

Samplings were performed for $8 \mathrm{~h}$ during daytime indoor (with the rooms normally occupied) and outdoor simultaneously. Measurements were taken for dry-wet bulb temperature and relative humidity, aldehydes, VOCs, total particulate matter (TPM) and airborne fungi.

Air sampling systems consisted of area stations equipped with diaphragm air sampling pumps with flowmeters (1 $\mathrm{L} \mathrm{min}^{-1}$ for VOCs and aldehydes and $10 \mathrm{~L} \mathrm{~min}^{-1}$ for TPM). Pollutants were concentrated by pumping air through a manifold containing sorbent tubes and filters.

Complete sampling and analysis conditions are described elsewhere. ${ }^{8,12}$ VOCs were collected on XAD-2 resin in series with activated charcoal in cartridges containing two sections each, one for sampling (100 mg) and other for checking possible breakthrough $(50 \mathrm{mg})$. The collected VOCs were directly extracted by dichloromethane in an autosampler vial. Perdeuterotoluene was used at $20 \mu \mathrm{g} \mathrm{mL}^{-1}$ as an internal standard. VOCs were quantified by high resolution gas chromatography with flame ionization detector (HRGC-FID) (Hewlett-Packard 5890 GC, Series II, Palo Alto, Calif. USA). The temperatures of the injector and detector were 260 and $290^{\circ} \mathrm{C}$, respectively. The column was an HP-5 fused silica capillary column (60 $\mathrm{m} \times 1.12 \mathrm{~mm}$ i.d. $\times 200 \mu \mathrm{m}$ film thickness). The GC heating profile was $5 \mathrm{~min}$ at $35^{\circ} \mathrm{C}$, being programmed at $10^{\circ} \mathrm{C}$ $\mathrm{min}^{-1}$ to $250^{\circ} \mathrm{C}$ and holding for $5 \mathrm{~min}$. The carrier gas was helium at $1.8 \mathrm{~mL} \mathrm{~min}^{-1}$ flow rate. Compounds were identified by high resolution gas chromatography coupled to mass spectrometry (HRGC-MS) (Hewlett-Packard 5890 GC, 


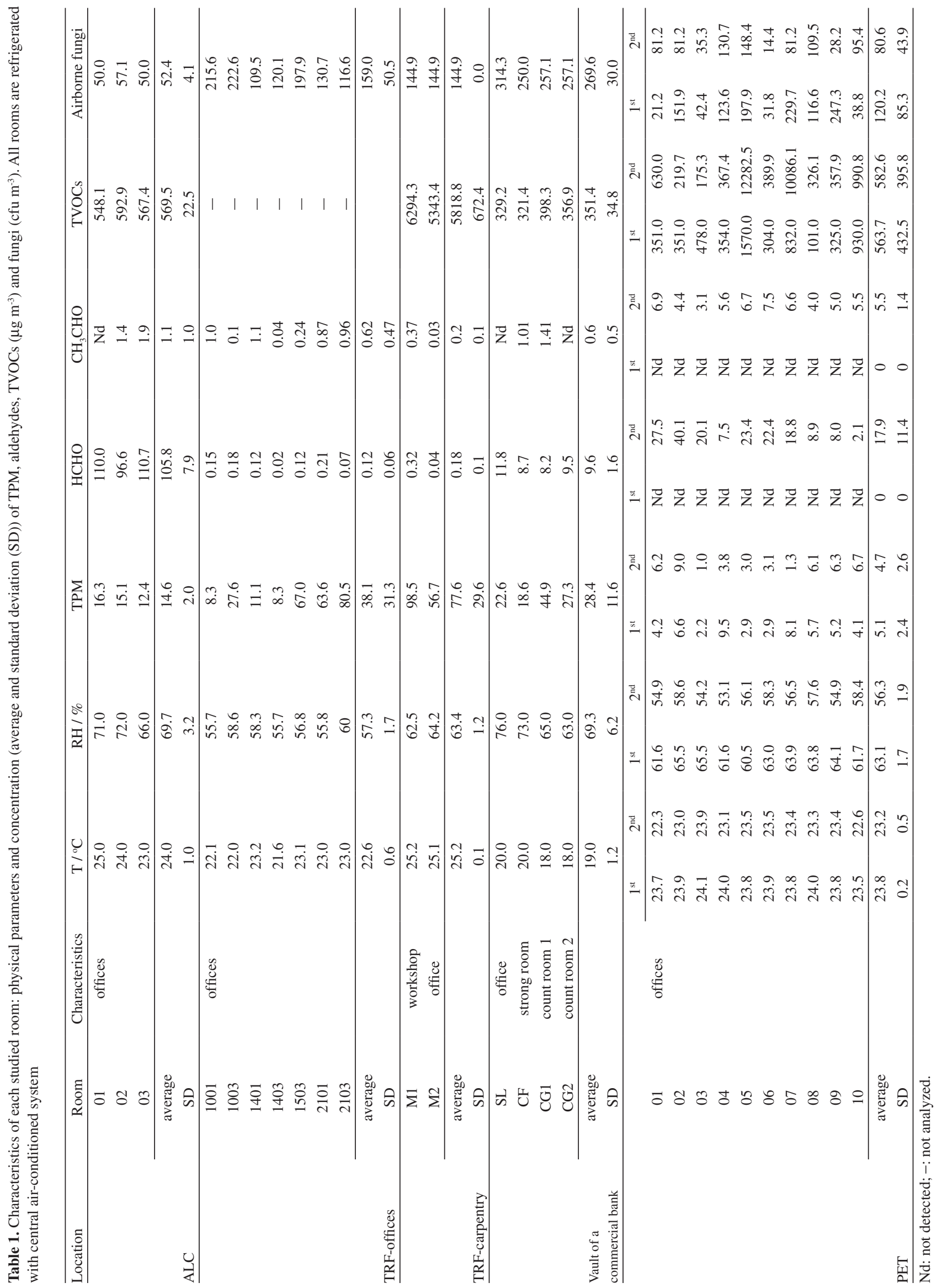


Series II/Hewlett-Packard 5972 Series Mass Selective Detector) and the analytical conditions were similar to those used in HRGC-FID analyses. The MS system was operated in the electron impact mode at $70 \mathrm{eV}$ with helium as the carrier gas, at $1.6 \mathrm{~mL} \mathrm{~min}^{-1}$ flow rate, $32 \mathrm{~cm}$ average linear velocity and $3.12 \mathrm{~min}$ hold-up. The limit of detection (LOD) varied from 0.01 to $0.1 \mu \mathrm{g} \mathrm{m}^{-3}$ depending on the different volatile organic compounds (VOCs) and the limit of quantification varied from 0.3 to $3 \mu \mathrm{g} \mathrm{m}^{-3}$. A calibration curve for the response factor was prepared for different VOC and the accuracy and precision of the determination was typically $\pm 10 \%$.

Samples to measure formaldehyde and acetaldehyde were collected on C18 Sep-Pak cartridges that were impregnated with an acid solution of 2,4-dinitrophenylhydrazine. Aldehyde samples were analyzed by isocratic high performance liquid chromatography (HPLC) (Waters $600 \mathrm{E}$, Miliford, Mass., USA), being the unit fitted with a variable wavelength ultraviolet detector adjusted to $360 \mathrm{~nm}$ (Hewlett-Packard Vis/UV Series 1100). The sample volume was $20 \mu \mathrm{L}$. Separation was performed on a C18 column (Merck Lichrocart C18 $125 \mathrm{~mm} \times 4.6 \mathrm{~mm} \times 5 \mu \mathrm{m}$ ). The flow of the acetonitrile/water (45:55) mobile phase was adjusted to $1 \mathrm{~mL} \mathrm{~min}^{-1}$. External standards containing six different concentrations of 2.4-dinitrophenilhydrazones of both aldehydes were analyzed under the same conditions. A calibration curve was made to quantify both derivatized aldehydes.

TPM was measured by gravimetric analysis. Air from the environment was collected on 37-mm diameter polycarbonate membrane filters ( $0.4 \mathrm{um}$ ) mounted in plastic cassettes. Filters were preconditioned to constant humidity in a desiccator containing $80 \%(\mathrm{~m} / \mathrm{m})$ glycerol/water before and after sampling. Weighing was performed on a calibrated microbalance $( \pm 0.00002 \mathrm{~g})$.

The air samples for microbiological analysis are of four distinct types: ambient air, supply air, return air and mixer air. The used sampler for these collections was a one stage CBI Air Sampler E01-S Impactor (CBI Air Sampler, Sao Paulo, Brazil). Fungi analysis conditions were described by Brickus et al. ${ }^{9}$

\section{Results and Discussion}

\section{Temperature and relative humidity}

Figure 1 illustrates the temperatures $(\mathrm{T})$ that were measured in the office buildings (ALC, TRF and PET), carpentry and a bank vault of a commercial bank.

ASHRAE ${ }^{18}$ recommends internal temperatures between 20-26 ${ }^{\circ} \mathrm{C}$ and Brazilian guidelines $s^{7} 23$ to $26^{\circ} \mathrm{C}$. The indoor temperature for all environments varied from 18 to $25^{\circ} \mathrm{C}$, with an average of $23^{\circ} \mathrm{C}$ that is the suggested minimum value by Brazilian guidelines. Some of the rooms presented temperature values below the minimum limit $\left(23^{\circ} \mathrm{C}\right)$, but none above $\left(26^{\circ} \mathrm{C}\right)$ (Figure 1, Table 1). ALC presented satisfactory temperatures for all rooms. In the vault, the detected lowest temperature was below the suggested minimum.

ASHRAE $^{18}$ recommends for relative humidity (RH) value a range from 30 to $70 \%$ and the $\mathrm{RE}^{7}$ from 40 to $65 \%$. The relative humidity was in the interval of $53-76 \%$, with an average value of $61 \%$. This value is near of the maximum one that is suggested by Brazilian guidelines

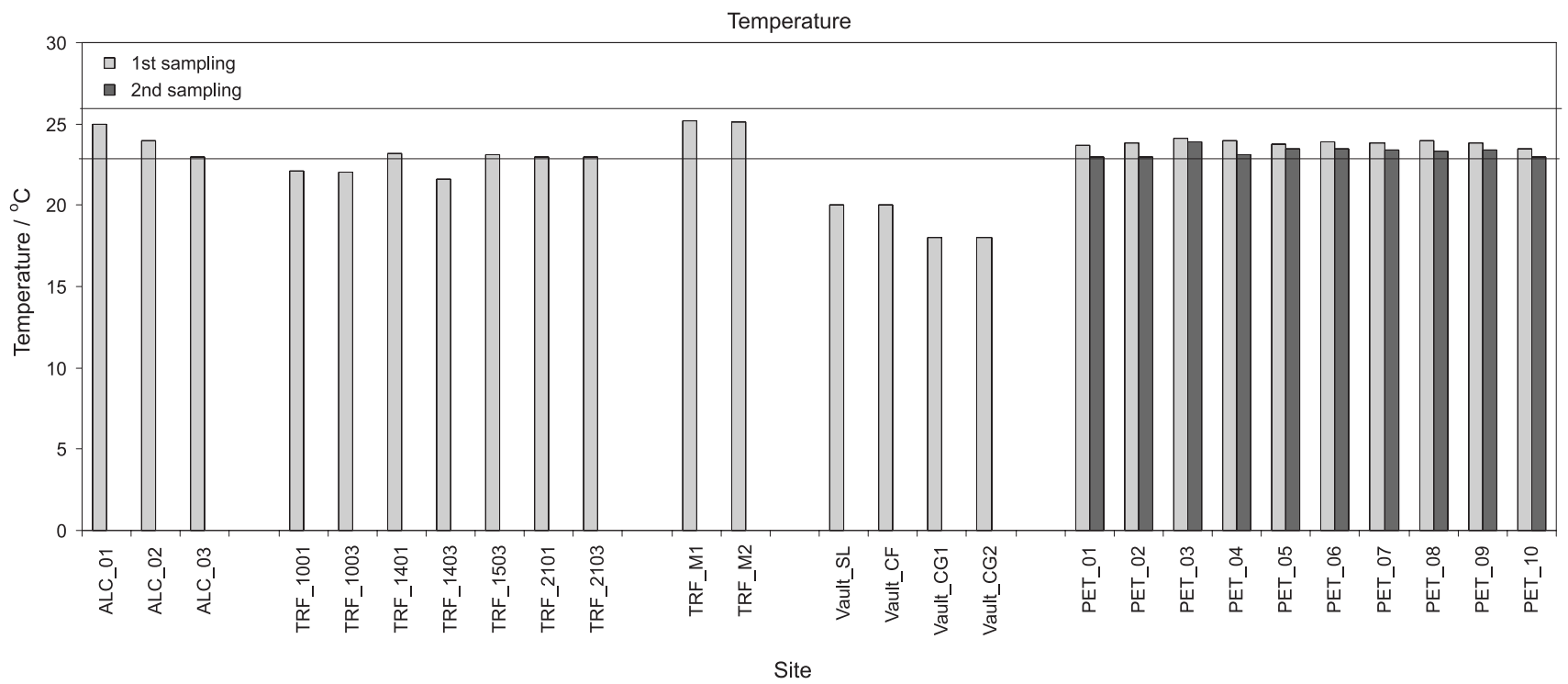

Figure 1. Temperature measured for all environments. Lines represent the minimum and maximum temperatures $\left(23\right.$ and $26{ }^{\circ} \mathrm{C}$, respectively) suggested by Brazilian guidelines. 


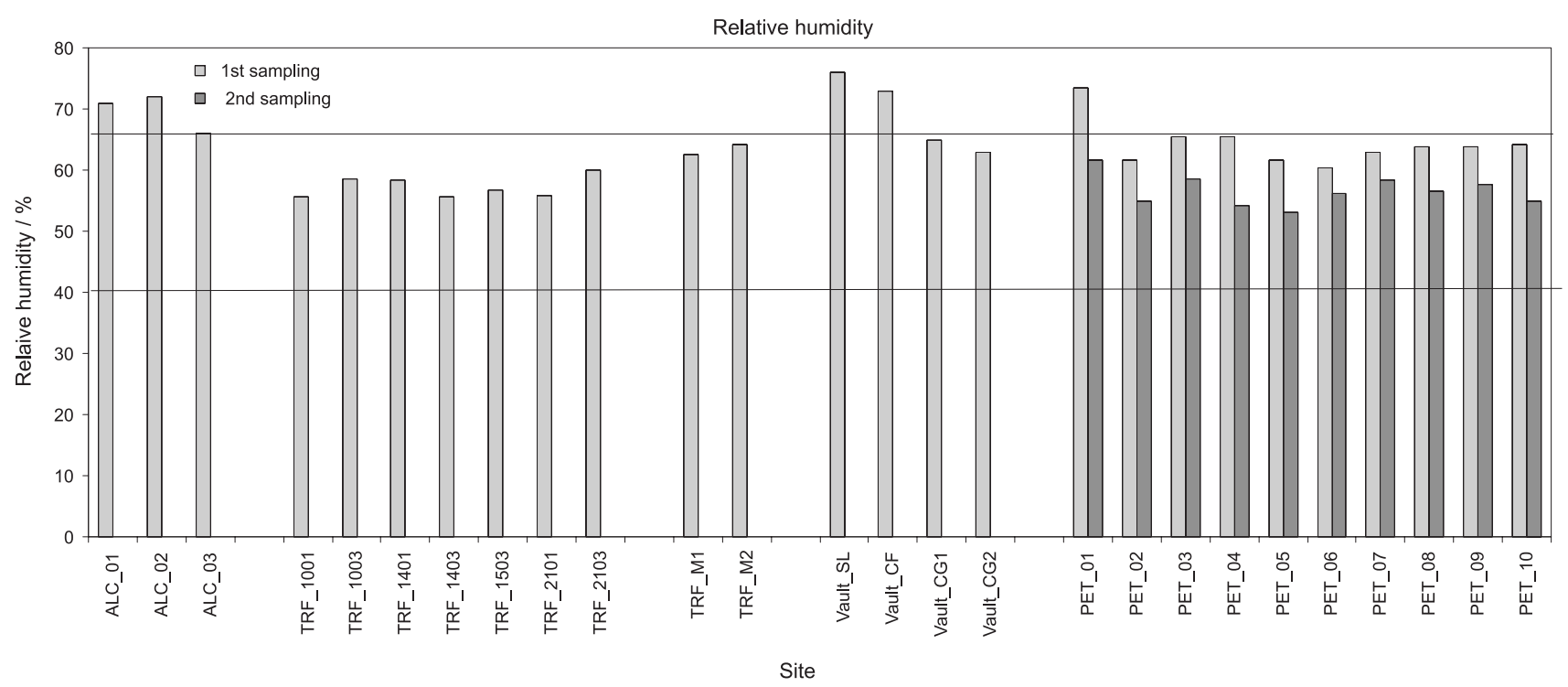

Figure 2. Relative humidity measured for all environments. Lines represent the minimum and maximum relative humidity (40 and $65 \%$, respectively) suggested by Brazilian guidelines.

(Figure 2, Table 1). In contrast to temperature, the RH values were near the maximum limit $(65 \%)$ with some of them exceeding, but none was lower than the minimum guideline value $(40 \%)$. The high $\mathrm{RH}$ value is probably due to external conditions since the average $\mathrm{RH}$ value in Rio de Janeiro is about $70 \%$ for the whole year. ${ }^{19}$

It is known that low air humidity values induce the drying of skin, mouth and nasal mucous while high values can favor the proliferation of biological agents. Temperature and humidity are also important due to their influence on the clearance rate of chemical pollutants from the environment. Although, most of the measurements are within the guideline values, they are near the maximum $(\mathrm{RH})$ or minimum $(\mathrm{T})$ values. In this case, low temperatures could be uncomfortable for their occupants and the high humidity could cause proliferation of microorganisms.

\section{Total particulate matter (TPM)}

TPM concentrations ranged from 0.1 to $99 \mu \mathrm{g} \mathrm{m}^{-3}$, with an average of $17 \pm 26 \mu \mathrm{g} \mathrm{m}^{-3}$. Overall, most of the measured TPM values were below the suggested limits by national guidelines $\left(80 \mu \mathrm{g} \mathrm{m}^{-3}\right)$ (Table 1). The highest values were measured in the carpentry that is an environment with intense activities and sources of particulate matter. The I/O ratios for these environments were higher than unit (1), indicating that indoor concentrations are higher than outdoors in these environments. Although many measurements were made on different floors of the buildings, it was not observed a decrease in the concentration depending on the floor height. It is expected that high-level floors are less impacted by outdoor pollution than ground-level floors. It means that in this study the main TPM sources are internal.

\section{Aldehydes}

Formaldehyde levels are good indicators of the effect of the air-conditioning regime in the indoor pollutant concentrations. ${ }^{8}$ Formaldehyde concentrations ranged between not detected to $111 \mu \mathrm{g} \mathrm{m}^{-3}$, with an average of $15 \pm 30 \mu \mathrm{g} \mathrm{m}^{-3}$ for all environments. In this study, the maximum levels of formaldehyde were slightly higher (just in few points) than the suggested limit $\left(100 \mu \mathrm{g} \mathrm{m}^{-3}\right){ }^{20}$ The sampling points with high formaldehyde levels were in the renewed office (ALC and PET - $2^{\text {nd }}$ sampling). Probably, it originated from phenolic resins that were used as a plywood binder and particleboard finishing materials, glues and furniture ${ }^{21}$ (due to the recent reform in the offices). The I/O ratios for all points were much higher than unit indicating an indoor source for this pollutant.

Low levels of acetaldehyde were detected for all office rooms varying between not detected and $8 \mu \mathrm{g} \mathrm{m}^{-3}$ (Table 1) that is much lower than the limit $\left(100 \mu \mathrm{g} \mathrm{m}^{-3}\right) .{ }^{20}$ It seems that this pollutant is not the cause of ill health problems in the occupants of this building. However, especially sensitive groups showing hypersensitive reactions without immunological signs could suffer some health problems, therefore World Health Organization (WHO ${ }^{20}$ recommends a maximum value of $10 \mu \mathrm{g} \mathrm{m}^{-3}$. The use of ethanol for cleaning surfaces (notably glass windows) in Brazil is very common. This appears to be the major source of acetaldehyde indoors because acetaldehyde is a usual contaminant in commercial ethanol. There was no evidence 
that its higher levels could derive from the use of ethanol as fuel for cars in Brazil.

\section{Volatile organic compounds (VOCs)}

Several VOCs were identified using a MS Chemstation with a Wiley 275.L spectral library and the mean concentrations of the main measured compounds $\left(\mu \mathrm{g} \mathrm{m}^{-3}\right)$ are listed in Table 2.

The commonly detected volatile organic compounds can be divided into five categories. The largest classes are the aromatic and aliphatic hydrocarbons. The compounds in these two classes are derived from petroleum products (e.g., solvents, fuel etc). Chlorinated hydrocarbons are commonly emitted from solvents, detergents, insecticides and tap water. ${ }^{22}$ The terpenes constitute a class of odoriferous substances that are probably related to cleaning products. Oxygenated compounds (aldehydes of high molecular weight) make up the remaining class.
The distribution of VOC classes in indoor air varies due to their different emission sources (Figure 3).

The absolute amount of the compounds also widely varied between the sampling sites. On average, about 20-30 compounds were identified in each office room and 50-60 in the carpentry. However, in most of them, the predominant classes were aliphatic and aromatic hydrocarbons. Only in a few sampling points were detected terpenes. Offices (PET and ALC) and vault presented similar class distributions for aromatics (43-48\%), chlorinated (1-3\%) and terpenes $(0-2 \%)$. However they presented significant differences for aliphatic (27, 37 and 44\%) and oxygenated (3, 14 and 28\%) compounds (Figure 3). In the carpentry, the predominant class was aromatic (70\%), followed by oxygenated (20\%) and aliphatic (10\%). No chlorinated or terpenes were found.

The aromatic compounds predominated in all the studied environments because they are major components of the solvents, inks and external infiltration. The indoor concentration is frequently much higher (e.g., toluene).

Table 2. Concentration ranges of the main VOCs identified $\left(\mu \mathrm{g} \mathrm{m}^{-3}\right)$

\begin{tabular}{|c|c|c|c|c|c|c|}
\hline Compound & Class & TRF-carpentry & PET & ALC & Vault & Outdoor \\
\hline 1,2-Dichloroetene & $\mathrm{CL}$ & - & $18-362$ & - & - & - \\
\hline 1-Ethyl-2-methylbenzene & AR & - & $1-15$ & - & - & - \\
\hline 1-Ethyl-2-methylcyclohexane & $\mathrm{AL}$ & - & $1-11$ & - & - & - \\
\hline 1-Ethyl-3-metilcyclohexane & $\mathrm{AL}$ & $1-1176$ & - & - & & 2 \\
\hline 1-Ethyl-4-methylhexane & $\mathrm{AL}$ & $\mathrm{Nd}-4$ & - & - & - & 3 \\
\hline 2-Methyl-1-decanol & OX & $\mathrm{Nd}-2$ & Nd-37 & - & - & 13 \\
\hline 2-Methyll-2-buthanol & $\mathrm{OX}$ & - & $1-15$ & - & - & - \\
\hline 4-Methyloctane & $\mathrm{AL}$ & - & Nd-86 & - & - & - \\
\hline Benzene & AR & - & Nd-492 & $1-2$ & $6-8$ & $1-4$ \\
\hline Butoxiethanol & OX & $1-1137$ & & $17-165$ & - & 1561 \\
\hline Decane & $\mathrm{AL}$ & - & $\mathrm{Nd}-55$ & & $3-8$ & $1-2$ \\
\hline Dichlorobenzene & AR & - & Nd-653 & - & $20-25$ & - \\
\hline Dimethyldecane & $\mathrm{AL}$ & $2-6$ & Nd-110 & - & & 50 \\
\hline Dodecane & $\mathrm{AL}$ & - & Nd-109 & - & $30-45$ & $1-2$ \\
\hline Ethanol & OX & $20-125$ & - & - & - & $8-9$ \\
\hline Ethylbenzene & AR & $11-969$ & Nd-185 & $29-30$ & $4-5$ & $4-1326$ \\
\hline Heptane & $\mathrm{AL}$ & $1-2$ & Nd-19 & - & - & 11 \\
\hline Hexane & $\mathrm{AL}$ & $40-323$ & $14-196$ & - & - & 178 \\
\hline Methylcyclohexane & $\mathrm{AL}$ & - & $2-1114$ & - & - & - \\
\hline Methylheptane & $\mathrm{AL}$ & - & $1-72$ & - & - & - \\
\hline Nonane & $\mathrm{AL}$ & $1-2$ & $\mathrm{Nd}-46$ & - & - & 40 \\
\hline Octane & $\mathrm{AL}$ & $5-6$ & $2-22$ & - & - & 48 \\
\hline Pentanone & $\mathrm{AL}$ & $1-2$ & Nd-69 & - & - & - \\
\hline Toluene & AR & $940-1900$ & 45-10916 & $118-121$ & $30-42$ & $15-3900$ \\
\hline Trimethylbenzene & $\mathrm{AR}$ & $2-12$ & - & $21-22$ & - & - \\
\hline Xylenes & AR & Nd-146 & $2-154$ & $26-27$ & $11-22$ & $8-215$ \\
\hline
\end{tabular}

Nd: not detected; -: not analyzed. 

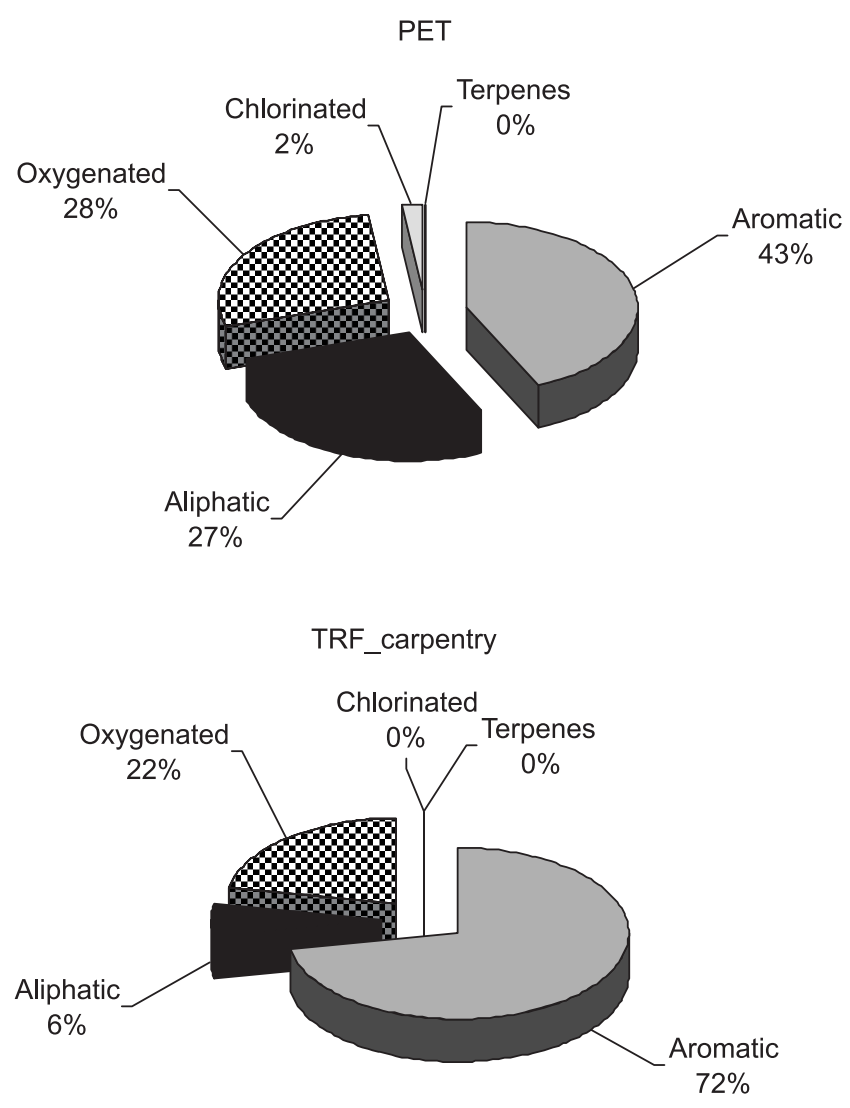
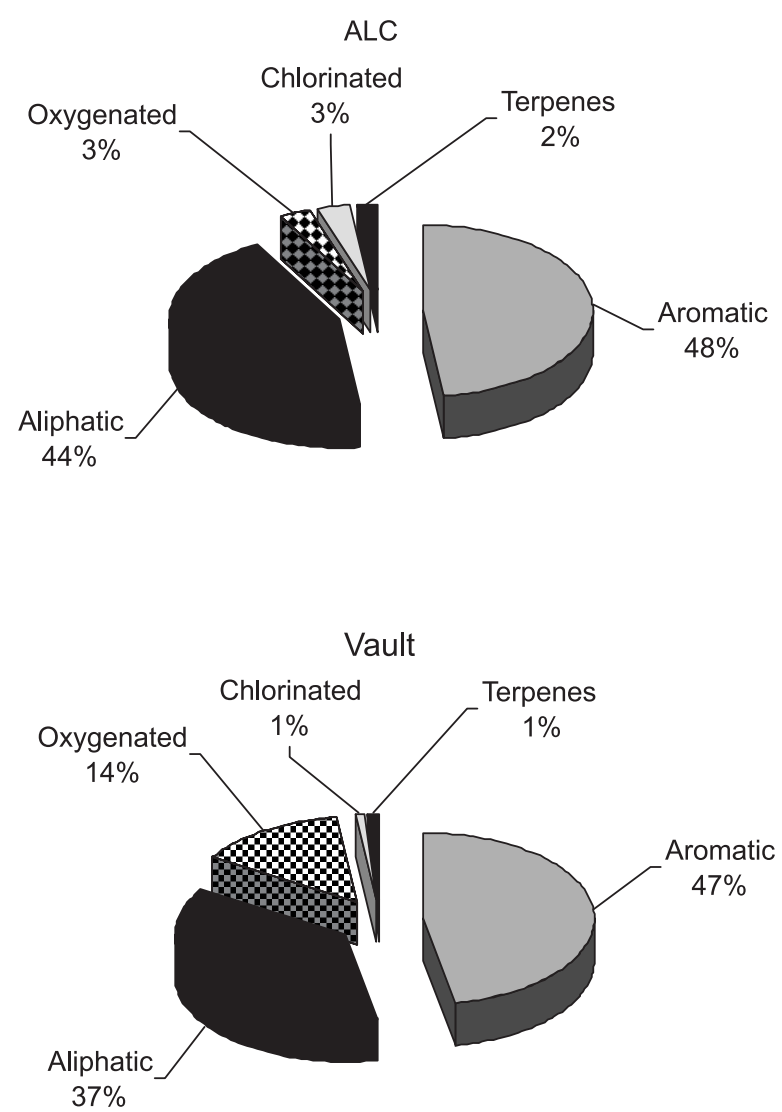

Figure 3. Average percentage of the main classes of volatile organic compounds obtained for each building.

There are many compounds that are only found indoor (e.g., 1-methyl-2-propylbenzene, 1,2-dimethylcyclohexane). The main compounds that were identified among the aromatics were benzene, toluene, ethylbenzene and xylene isomers. They are identified as target compounds in environmental studies due to their potential health risks. There is no regulation for a tolerance limit for any of the identified compounds. On the other hand, some common harmful compounds have very high (in regards to indoor pollution) industry environment limits determined by NR-15, ${ }^{23}$ e.g., toluene and xylenes (290 and $340 \mathrm{mg} \mathrm{m}^{-3}$, respectively). However, Aquino Neto and Brickus ${ }^{24}$ recommended a guideline for individual VOCs of $250 \mu \mathrm{g} \mathrm{m}^{-3}$ for indoor environments. Toluene showed the greatest concentration in the majority of the sampling points. Indoor concentrations ranging from 5 to $2043 \mu \mathrm{g} \mathrm{m}^{-3}$ for toluene and $10-1500 \mu \mathrm{g} \mathrm{m}^{-3}$ for xylenes were measured (Table 2). The office environments presented low levels of these aromatics, but the carpentry showed the highest levels. This was expected due to the kind of activity, exceeding the suggested limit.

The saturated hydrocarbons can be originated from a variety of consumer products, building materials, where they are present as solvents or thinners and in building composites (particleboard). Some may also arise from tobacco smoke and vehicular traffic. ${ }^{5}$ Several kinds of alkanes and cycloalkanes were identified such as n-alkanes, methylcyclohexane, methyl and ethyl cyclohexanes and others (Table 2). However, the exact structures of several isomers of the other alkanes and cycloalkanes were not characterized.

In general, the levels of individual aliphatic VOCs are low in the offices. For ALC, the highest concentration was obtained for pentadecane $\left(c a .7 \mu \mathrm{g} \mathrm{m}^{-3}\right)$. For the vault, it was decane $\left(c a .8 \mu \mathrm{g} \mathrm{m}^{-3}\right)$. On the other hand, the aliphatic compounds were high in the carpentry, where hexane (ca. $320 \mu \mathrm{g} \mathrm{m}^{-3}$ ) exceeded the suggested limit $\left(250 \mu \mathrm{g} \mathrm{m}^{-3}\right)$.

Some oxygenated compounds were detected in significant concentrations in the carpentry, such as ethanol (21-125 $\mathrm{g} \mathrm{m}^{-3}$ ) and 3-hydroxy-2-butanone (ca. $14 \mu \mathrm{g} \mathrm{m}^{-3}$ ). Among the studied office sites, it was detected methylpentanone ( $c a .121 \mathrm{\mu g} \mathrm{m}^{-3}$ ) and 2,2-dimethylpropanol ( $c a .441 \mu \mathrm{g} \mathrm{m}^{-3}$ ) that presented the highest mean concentrations. The latter ones surpass the values that are suggested by Aquino Neto and Brickus. ${ }^{24}$

TVOC values are very useful in the assessment of the quality of the indoor air. Molhave and Clausen ${ }^{25}$ proposed the use of a target guideline of $300 \mu \mathrm{g} \mathrm{m}^{-3}$ for TVOC as an indicator of ill health effects that are caused by a multicomponent air exposure to VOC at low concentrations. In Brazil, Aquino Neto and Brickus ${ }^{24}$ recommended a 
guideline for TVOCs of $500 \mu \mathrm{g} \mathrm{m}^{-3}$. These measurements demonstrated that values of TVOC concentrations in the evaluated sites are high enough, in the light of the study performed by Molhave and Clausen, ${ }^{25}$ to cause discomfort in occupants (especially sensitive individuals). In this study, the TVOC values ranged from 100 to $12282 \mu \mathrm{g} \mathrm{m}^{-3}$, with an average of $1594 \pm 3020 \mu \mathrm{g} \mathrm{m}^{-3}$. Figure 4 and Table 1 show TVOC values for all sampling points.

According to recommended Brazilian threshold $\left(500 \mu \mathrm{g} \mathrm{m}^{-3}\right)$, just the offices in the vault presented appropriated levels of TVOC, with similar concentrations among rooms (321-398 $\left.\mathrm{g} \mathrm{m}^{-3}\right)$. In the ALC offices were measured slightly higher levels of TVOCs, but it was also similar among the rooms (548-592 $\left.\mu \mathrm{g} \mathrm{m}^{-3}\right)$. Levels in the carpentry were very high, mainly in the workshop $\left(6294 \mathrm{~g} \mathrm{~m} \mathrm{~m}^{-3}\right)$. This was expected due the more intense activities than in the office. In the PET building, most of the rooms presented low levels of TVOCs in the first sampling, but high in the second one (after renovation of the room). As expected, the concentrations of TVOCs increased as a reflection of the increased emission of these substances from building materials and finishing (plywood, glues, paints, varnishes, wax, etc). Also, there are significant differences among the levels in the building. It is not clear the cause of these variations once the rooms are located in the same floor and composed by the same materials and number of workers.

Indoor/outdoor ratios for VOC classes and TVOC revealed that indoor air is much more polluted than outdoor, with critical sources of pollution. ${ }^{26-28}$ This fact indicates that VOCs found in indoor environments are originated mainly from indoor sources, possibly because of the materials used in refurbishing, and cleaning products.

\section{Airborne fungi}

Microbiological analysis shows similar characteristics for all environments, presenting genera Alternaria, Penicilium, Aspergillus sp and Cladosporium in a significantly prevalent way in all samples. Exposures to species of Penicilium and Aspergillus sp have been associated with occupational asthma and hypersensitive pneumonitis. ${ }^{9}$ However, the levels that were detected for airborne fungi in this study (Table 1) are lower than the recommended by Brazilian guidelines $\left(750 \mathrm{cfu} \mathrm{m}^{-3}\right){ }^{7}$ Although the temperature and relative humidity are out of the suggested range in most of the sites, it seems not to affect the microbiological growth. No correlation among $\mathrm{RH}$ and $\mathrm{T}$ with fungi concentrations was obtained. These low measured levels of airborne fungi indicate that the air-conditioning systems are kept working properly in these buildings.

Comparison with other published studies from Rio de Janeiro

In Brazil, indoor air quality research is very limited if one considers the sheer size of the country and the predominance of a tropical climate, demanding the use of air-conditioners due to high temperatures. Therefore, nowadays there is a tendency to construct sealed buildings, which could cause an increase of sick building symptoms (SBS). The importance of the indoor air quality studies is to try to determine average values for concentrations for indoor environments to establish federal laws to protect public health. To define a profile for the whole country, a

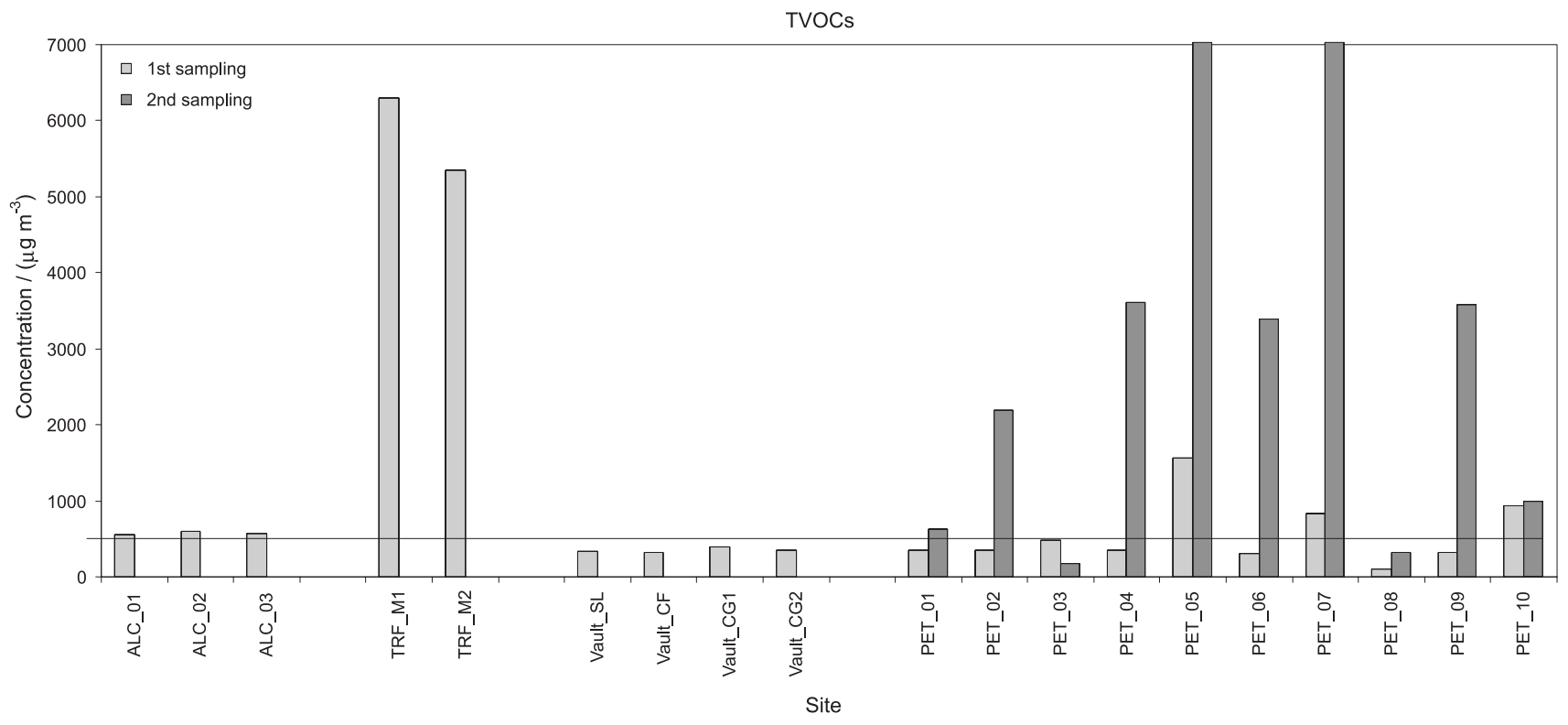

Figure 4. Indoor TVOC concentrations for all indoor environments and the suggested limit $\left(500 \mu \mathrm{g} \mathrm{m}^{-3}\right)$. 
larger number of studies in different regions and indoor environments would be necessary.

In order to define a profile of pollutant distribution, a compilation of data was done. Table 3 presents published concentrations of TPM, aldehydes, TVOCs and airborne fungi for Rio de Janeiro City. These values are compared with this study. In this research, other buildings were investigated, but other profiles were observed. Overall, the levels of indoor pollutants significantly vary among sites as discussed below for each species.

Total particulate matter presented low levels in most of the studied environments, both with and without central air-conditioning systems (Table 3). However, in other offices with air-conditioning or natural ventilation, high levels were detected ranging from 130 to $1930 \mu \mathrm{g} \mathrm{m}^{-3}$. These levels exceed by several times the limit that is suggested by the Brazilian legislation $\left(80 \mu \mathrm{g} \mathrm{m}^{-3}\right){ }^{7}$ Probably, the cause of these higher concentrations is the downtown city location, near streets with heavy traffic. Restaurants with electrical systems for food cooking presented levels between 54-84 $\mu \mathrm{g} \mathrm{m}^{-3}$ being lower than the ones measured for charcoal systems $\left(408 \mu \mathrm{g} \mathrm{m}^{-3}\right){ }^{4}$

Aldehydes were detected in low levels being not detected in most cases. In this study, the highest registered concentrations for formaldehyde among sites were

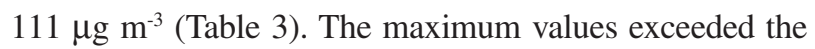
suggested limit of $100 \mu \mathrm{g} \mathrm{m}^{-3}$. According to these results, and contrarily to the expected contribution of ethanol as car fuel in Rio de Janeiro, aldehydes do not appear to be the most important pollutant of indoor environments.

Total volatile organic compounds largely varied among sites. The lowest registered concentrations were in a library (64-199 $\mu \mathrm{g} \mathrm{m}^{-3}$ ) and restaurants (7-182 $\mu \mathrm{g} \mathrm{m}^{-3}$ ) (Table 3). The measured concentration in residences was surprisingly high ranging from 800 to $1000 \mu \mathrm{g} \mathrm{m}^{-3}$. Probably, the outdoor sources had significant influence in these concentrations. But also cleaning activities with solvents and other products and cooking affected the levels of TVOCs. Comparing offices with natural and central ventilation, it was observed that the former presented higher TVOC concentrations. The worst scenario with concentration as high as $46000 \mu \mathrm{g} \mathrm{m}^{-3}$ was obtained in a printing facility. These high values were expected as several kinds of solvents and inks were handled in that environment.

Regarding to microbiological analysis, in this study, low levels of airborne fungi were detected (20-314 $\mathrm{cfu} \mathrm{m}^{-3}$ ). The highest levels were detected in a research laboratory. Probable the cause of these high concentrations is the location, in a basement with high humidity. Overall, the microbiological index did not exceed the suggested limit $\left(750 \mathrm{cfu} \mathrm{m}^{-3}\right){ }^{7}$

According to Table 3, the concentrations of chemical pollutants largely varied among indoor environments. These differences are partially due to the characteristics

Table 3. Comparison between the published ranges of concentrations ( $\mu \mathrm{g} \mathrm{m}^{-3}$ ) and fungi for indoor pollutants measured in different indoor environments in Rio de Janeiro, Brazil

\begin{tabular}{|c|c|c|c|c|c|c|c|}
\hline Sites & $\begin{array}{l}\text { Air-conditioning } \\
\text { system }\end{array}$ & TPM & Formaldehyde & Acetaldehyde & TVOCs & $\begin{array}{l}\text { Airborne fungi / } \\
\quad\left(\mathrm{cfu} \mathrm{m}^{-3}\right)\end{array}$ & Reference \\
\hline ALC (offices) & central & $12-16$ & $97-111$ & Nd-1.9 & $548-593$ & $50-57$ & this study \\
\hline TRF (offices) & central & $8.3-81$ & $0.02-0.2$ & $0.04-1.0$ & - & $109-222$ & this study \\
\hline $\begin{array}{l}\text { PET (offices): } \\
1^{\text {st }} \text { sampling } \\
2^{\text {nd }} \text { sampling }\end{array}$ & central & $\begin{array}{l}2-8.1 \\
1-9.0\end{array}$ & $\begin{array}{c}\mathrm{Nd} \\
3-39\end{array}$ & $\begin{array}{c}\mathrm{Nd} \\
3-7.6\end{array}$ & $\begin{array}{c}100-1570 \\
326-12282\end{array}$ & $\begin{array}{l}21-247 \\
14-148\end{array}$ & this study \\
\hline Vault & central & $19-45$ & 8-12 & ND-1.4 & $321-398$ & $250-314$ & this study \\
\hline TRF (carpentry) & central & $57-99$ & $0.04-0.3$ & $0.03-0.4$ & $5345-6294$ & 145 & this study \\
\hline $\begin{array}{l}\text { Printing facility: } \\
1^{\text {st }} \text { sampling } \\
2^{\text {nd }} \text { sampling }\end{array}$ & central & $\begin{array}{c}6-61 \\
13-37\end{array}$ & $\begin{array}{c}6-35 \\
13-37\end{array}$ & $\begin{array}{c}1-21 \\
10-34\end{array}$ & $\begin{array}{l}2746-46154 \\
1962-17412\end{array}$ & $\begin{array}{c}100-343 \\
-\end{array}$ & 12 \\
\hline $\begin{array}{l}\text { Offices } \\
\text { Offices }\end{array}$ & $\begin{array}{l}\text { central } \\
\text { natural }\end{array}$ & $\begin{array}{l}133-1933 \\
300-1933\end{array}$ & - & - & $\begin{array}{c}42-774 \\
463-1566\end{array}$ & $-57-480$ & 10 \\
\hline $\begin{array}{l}\text { Restaurants } \\
\text { Offices }\end{array}$ & $\begin{array}{l}\text { central } \\
\text { central }\end{array}$ & $\begin{array}{l}54-408 \\
38-103\end{array}$ & $\begin{array}{c}5-11 \\
14-38\end{array}$ & $\begin{array}{c}6-69 \\
24-59\end{array}$ & $\begin{array}{c}7-182 \\
10-568\end{array}$ & - & 4,5 \\
\hline Offices & central & $48-92$ & $12-100$ & $2-36$ & $304-1680$ & $141-205$ & 8,9 \\
\hline Library & split & $14-43$ & $0.4-4$ & $0.4-4$ & $275-345$ & - & 29 \\
\hline Research laboratory & central & $<1$ & $\mathrm{Nd}$ & $\mathrm{Nd}$ & $920-1450$ & $1222-3598$ & 30 \\
\hline Residences & natural & 48 & 40 & - & $800-1000$ & - & 11 \\
\hline
\end{tabular}

Nd: not detected; -: not analyzed. 
of each environment. However, some variations could be also attributed to sampling methodologies, period of the year and other factors. It is urgently needed to validate the methodology for indoor sampling and analyses in order to gain more reliable information about indoor pollutants. Interlaboratory proficiency testing should be also established to reach consensus values among laboratories that work in this field, integrating that obtained values worldwide. Based only in the few available results, it is very difficult to define thresholds due to great variations, although it was observed in the same kind of indoor environment.

Indoor air was monitored in different environments in Rio de Janeiro City in order to get information to be used in governmental guidelines. Because of the potential risks and problems related to indoor air pollution, the Brazilian government has been striving to establish IAQ objectives for different types of indoor environments.

Indoor air quality study is a complex issue and requires multidisciplinary investigations and environmental monitoring. To understand the effects of the indoor air on the occupants, an evaluation of the performance of the building and a survey about materials, activities, cleaning products and health symptoms are required. It is essential to characterize the composition, magnitude and the distribution of air toxicants through air monitoring, assessing the impact of these components on human health. It is important to take into account that new and refurbished buildings have generally materials that could emit high indoor concentrations of VOCs and formaldehyde, causing adverse effects on the occupants. Good practices of environmental monitoring and sampling of pollutants for assessment of the impacts together with a medical evaluation are essential to improve IAQ guidelines.

\section{Conclusions}

In this study, physical parameters, such as temperature and relative humidity, were evaluated and oscillated among rooms. For most sites, the temperature was near the minimum value $\left(23{ }^{\circ} \mathrm{C}\right)$ and the relative humidity near to the maximum value $(65 \%)$ that is suggested by Brazilian guidelines. These values out of the guidelines range could be uncomfortable for the occupants or cause proliferation of microorganisms. In spite of the high $\mathrm{RH}$, low levels of fungi were observed. The low measured levels of airborne fungi indicates that the air-conditioning systems are kept working properly in these buildings. The total particulate matter (TPM) was measured in lower levels (average of $17 \mu \mathrm{g} \mathrm{m}^{-3}$ ) than the suggested by the guideline $\left(80 \mu \mathrm{g} \mathrm{m}^{-3}\right)$, indicating as clean the studied environments. Some places with more intense activities had high TPM concentrations, slightly exceeding the limits. Formaldehyde and acetaldehyde were detected in low concentrations in almost all rooms. The level of formaldehyde was higher in newly built homes and decreased with the age of the buildings. The average values of VOCs were associated with very large standard deviations, reflecting wide distribution of these compounds in indoor environments. The average concentration was $1543 \pm 3020 \mu \mathrm{g} \mathrm{m}^{-3}$ which is higher than the suggested limit $\left(500 \mu \mathrm{g} \mathrm{m}^{-3}\right)$. Compared to other studies in Brazil, the levels of formaldehyde and TVOCs are within the same range. The possible influence of the building age, its decoration, cigarette smoking and the number of occupants in indoor are the main causes of differences.

The mean values obtained in this work together with others conducted in Brazil were associated with very large standard deviation, reflecting wide distribution of chemical compounds and TPM. Both the indoor and outdoor environments have sources that elevated the indoor concentrations in a different extent. These variations are due to specific characteristics of each evaluated environment. Also, significant variations were observed among rooms of the same building. However, to define thresholds it is necessary to perform further studies to obtain a wider range of emission levels for each type of environment. Although in many rooms the parameters were within the guidelines, many symptoms were reported by the occupants. It means that the limits are still inadequate, especially for sensitive people.

\section{Acknowledgments}

The authors thank Conselho Nacional de Desenvolvimento Científico e Tecnológico (CNPq), Fundação de Apoio à Pesquisa do Estado do Rio de Janeiro (FAPERJ) and Fundação Universitária José Bonifácio (FUJB).

\section{References}

1. Jones, A. P.; Atmos. Environ. 1999, 33, 4535.

2. Grosjean, D.; Miguel, A. H.; Tavares, T. M.; Atmos. Environ. 1990, 24B, 101.

3. Allen, A. G.; Miguel, A. H.; Atmos. Environ. 1995, 29, 3519.

4. Miguel, A. H.; Aquino Neto, F. R.; Cardoso, J. N.; Vasconcellos, P. D. C; Pereira, A. S.; Marquez, K. S. G.; Environ. Sci. Technol. 1995, 29, 338.

5. Santos, C. Y. M.; Aquino Neto, F. R.; Cardoso, J. N.; Indoor Built Environ. 1997, 6, 168.

6. Ministério da Saúde; Qualidade do Ar (Sistemas de Climatização), Portaria No. 3523 de 28 de agosto de 1998, Brasília, DF, Brasil, 1998. 
7. Agencia Nacional de Vigilância Sanitária (ANVISA); Padrões Referenciais de Qualidade do Ar Interior em Ambientes Climatizados Artificialmente de Uso Público e Coletivo, Resolution - RE No. 9, Brasília, DF, Brasil, 2003.

8. Brickus, L. S. R; Cardoso, J. N.; Aquino Neto, F. R.; Environ. Sci. Technol. 1998a, 32, 3485.

9. Brickus, L. S. R.; Siqueira, L. F. G.; Aquino Neto, F. R.; Cardoso, J. N.; Indoor Built Environ. 1998b, 7, 270.

10. Rios, J. L. M.; Boechat, J. L.; Gioda, A.; Santos, C. Y. M.; Aquino Neto, F. R.; Silva, J. R. L.; Environ. Int. 2009, 35, 1136.

11. Almeida, S. M.; Corrêa, M. A. P.; Brickus, L. S. R.; Aquino Neto, F. R.; Moreira, J. M.; In: Healthy Buildings 2000, Helsinki, Finland, Proceedings V I Helsinky: SIY, 549.

12. Gioda, A.; Aquino Neto, F. R.; Indoor Built Environ. 2002, 11, 302.

13. Brickus, L. S. R.; Aquino Neto, F. R.; Quim. Nova 1999, 22 , 65 .

14. Gioda, A.; Aquino Neto, F. R.; Quim. Nova 2003, 26, 359.

15. World Health Organization (WHO); The Right to Healthy Indoor Air, Report on a WHO Meeting; WHO Regional Office of Europe: Bilthoven, Netherlands, 2000.

16. Wolkoff, P.; Clausen, P. A.; Nielsen, G. D.; Indoor Air 2006, $16,7$.

17. http://www.macalester.edu/courses/geog61/chad/geograph.htm Geography and Development of Rio de Janeiro, accessed in September 2011.

18. American Society of Heating, Refrigerating and AirConditioning Engineers (ASHRAE); Ventilation for Acceptable Indoor Air Quality, Standard 62-1999, ASHRAE, Inc.: Atlanta, 1999.
19. Martins, E. M.; Arbilla, G.; Atmos. Environ. 2003, 37, 1715.

20. World Health Organization (WHO); Indoor Air Quality: Biological Contaminants, Report on WHO Meeting; WHO Regional Office of Europe: Rautavaara, 1988, p. 37.

21. Sato, S.; Hirokawa, Y.; Bougaki, K., Ito, H.; Kimituki, M.; In: Healthy Build. 2000, Helsinki, Finland, Proceedings V I Helsinky: SIY 1, 459.

22. Iwata, T.; Ozaki, J.; Takahashi, M.; Kimura, K.; In:. Healthy Build. 2000, Helsinki, Finland, Proceedings V I Helsinky: SIY $1,407$.

23. Ministério do Trabalho; Segurança e Medicina do Trabalho: Lei No. 6514; Editora Atlas: São Paulo, Brasil, 1994.

24. Aquino Neto, F. R.; Brickus, L. S. R.; Rev. Brasindoor 1999, 3,4 .

25. Molhave, L.; Clausen, G.; Proceeding of $7^{\text {th }}$ International Conference on Indoor Air Quality and Climate, Nagoya, Japan, 1996, 2, 37.

26. Han, K. H.; Zhang, J. S.; Knudsen, H. N.; Wargocki, P.; Chen, H.; Varshney, P. K.; Guo, B.; Atmos. Environ. 2011, 45, 3034.

27. Lindgren, T.; Build. Environ. 2010, 45, 596.

28. Wolkoff , P.; Nielsen, G. D.; Environ. Int. 2010, 36, 788.

29. Gioda, A.; Ramos, M. C. K. V.; Aquino Neto, F. R.; Proceeding of $12^{\text {th }}$ International Conference on Indoor Air Quality and Climate, Austin, Texas, 2011, 6.

30. Freitas, T.; Research Laboratory in Indoor Air Quality; a Report for LADETEC, Rio de Janeiro, Brasil, 2005, 10. With the permission of author Freitas, T., this report is available under request.

Submitted: March 16, 2011

Published online: September 20, 2011 